\title{
Electrochemical $\mathrm{NO}_{2}$ Sensors with $\mathrm{WO}_{3}$ Electrodes for High Temperature Applications
}

\author{
$\mathrm{WO}_{3}$ を電極補助相とする高温用電気化学 $\mathrm{NO}_{2}$ センサー \\ Maria Luisa GRILLI, Narin KAABBUATHONG, Atanu DUTTA, \\ Elisabetta Di BARTOLOMEO and Enrico TRAVERSA \\ Dipartimento di Scienze e Tecnologie Chimiche, Università di Roma "Tor Vergata," Via della Ricerca Scientifica, o0133 Rome, Italy
}

\begin{abstract}
Electrochemical NO sensors for high temperature applications were prepared coupling pellets of yttriastabilized zirconia (YSZ), an oxygen ion conductor, with a thick film of a semiconducting oxide $\left(\mathrm{WO}_{3}\right.$ ) as an auxiliary phase. The obtained sensors were exposed to the same atmosphere without the use of reference air. Electromotive force (EMF), polarization curves and amperometric measurements were performed in air and at different concentrations of $\mathrm{NO}_{2}$ in air, at selected temperatures. Stable EMF values and fast response times were obtained. The sensors showed non-linear polarization curves. The role played by the electrolyte/ electrode interface was determined by electrochemical impedance spectroscopy (EIS) tests: exposure to $\mathrm{NO}_{2}$ did not affect the bulk but only the electrolyte/electrode interface.
\end{abstract}

[Received October 22, 2001; Accepted January 22, 2002]

Key-words : $\mathrm{NO}_{2}$, Electrochemical sensor, Stabilized zirconia, Oxide electrode, $\mathrm{WO}_{3}$

1. Introduction

The growing concern for air pollution is mainly due to combustion facilities, most of all to emissions of automotive vehicles. For this reason, international standards recently introduced on-board diagnostic (OBD) methods to continuously monitor gas exhaust concentrations. At present, the control of $\mathrm{NO}_{x}, \mathrm{HCs}$ and $\mathrm{CO}$, the main pollutants coming from automotive emissions, is obtained using the three-way catalytic converter coupled with an oxygen sensor based on yttria-stabilized zirconia (YSZ). 1) This potentiometric sensor, commonly called lambda probe, allows control of the air/fuel ratio at the stoichiometric value to optimise hydrocarbons and $\mathrm{CO}$ oxidation, and $\mathrm{NO}_{x}$ reduction in the three-way catalytic converter. ${ }^{2)}$ Because reliable $\mathrm{NO}_{x}, \mathrm{CO}$ and $\mathrm{HCs}$ sensors for the detection in exhausts are still not available, another oxygen sensor placed in the exhaust stream after the catalytic converter is used to comply with OBD requirements. From the difference between the electrical signals of the two oxygen sensors placed before and after the catalytic converter, using complex mathematical algorithms, it is possible to obtain an indirect evaluation of pollutants' concentration and infer the catalyst conversion efficiency. The availability of reliable $\mathrm{NO}_{x}, \mathrm{CO}$ and $\mathrm{HCs}$ sensors would allow a direct and fast analysis of pollutants concentration allowing better OBD systems to be applied in future vehicles. ${ }^{3)}$

For combustion control and exhaust monitoring, sensors should operate at high temperatures and in harsh environments. Therefore ceramic electrochemical sensors, like the YSZ oxygen sensors, seem to be the best candidates for these applications. However, most of the equilibrium-potential $\mathrm{NO}_{x}$ sensors use nitrites or nitrates as auxiliary phases in combination with a $\mathrm{Na}^{+}$ionic conductor. ${ }^{4)}$ The main problem of these sensors is the lack of thermal and chemical stability due to the low melting point of the auxiliary phases. $\left.{ }^{5}\right)$

A novel approach to allow the development of stable electrochemical $\mathrm{NO}_{x}$ sensors is the use of a metal oxide as an auxiliary phase replacing the oxyacid salts. ${ }^{6)-8}$ ) The same approach was used also for the development of similar electrochemical sensors for the detection of other gases. ${ }^{9), 10)}$ Sensors based on coupling YSZ with metal oxide electrodes are also reported in the relevant literature for detecting $\mathrm{NO}_{x}{ }^{11)-15)}$ or $\mathrm{CO} /$ hydrocarbons. ${ }^{16), 17)}$ These sensors are simple modifications of the well-established lambda probe. Thus, their technological transfer to automotive applications is supposed to be very easy. The oxide electrodes used as auxiliary phases can act also as catalysts increasing the selectivity of the devices. Some advantages for detecting low $\mathrm{NO}_{x}$ concentrations can be obtained operating these sensors in amperometric way. ${ }^{18), 19)}$

This work reports a study on solid-state ceramic $\mathrm{NO}_{x}$ sensors based on coupling an n-type semiconducting oxide $\left(\mathrm{WO}_{3}\right)$ with an ionic conductor (YSZ). $\mathrm{WO}_{3}$ has been selected because of its excellent performance in semiconductor $\mathrm{NO}_{2}$ sensors. ${ }^{20), 21)} \mathrm{WO}_{3}$ coupled with half open YSZ tubes were also found to give good sensing properties to NO and $\mathrm{NO}_{2} \cdot{ }^{13)}$ Thus, selective $\mathrm{NO}_{2}$ detection is expected using this oxide as auxiliary phase.

\section{Experimental procedure}

Commercial YSZ powders (Tosoh, 8 mass\% of yttria) were isostatically pressed at $200 \mathrm{MPa}$ and sintered at $1450^{\circ} \mathrm{C}$ for $8 \mathrm{~h}$ into disks of $10 \mathrm{~mm}$ in diameter and $0.5 \mathrm{~mm}$ in thickness. A drop of Pt paste was applied on a small area of one side of the solid electrolyte as a current collector. On the opposite side of the disk, the Pt paste was deposited on a circle area of $7 \mathrm{~mm}$ in diameter as a reference electrode. $\mathrm{Pt}$ paste was heated at a rate of $5^{\circ} \mathrm{C} / \mathrm{min}$ soaking for $1 \mathrm{~h}$ at $750^{\circ} \mathrm{C}$. Scanning electron microscopy (SEM) analysis of the $\mathrm{Pt}$ electrode showed a porous structure made of plate-like grains of micrometric dimension. ${ }^{15)}$ Commercial $\mathrm{WO}_{3}$ powders (purity 99.99\%) were used for the oxide electrodes. The average particle size of $\mathrm{WO}_{3}$ powders was $300 \mathrm{~nm}$, as observed by SEM analysis. The $\mathrm{WO}_{3}$ powders were mixed with a screen-printing oil and the slurry obtained was deposited on one side of the solid electrolyte pellets covering an area wider than the Pt electrode. Films were fired at $750^{\circ} \mathrm{C}$ for $3 \mathrm{~h}$ in air, with a heating rate of $5^{\circ} \mathrm{C} / \mathrm{min}$. After firing, an increase in the mean grain size was observed for $\mathrm{WO}_{3}$, up to $800 \mathrm{~nm}$. Electrochemical characterization was performed on the following cell:

$$
\mathrm{NO}_{2} \text { in air, } \mathrm{WO}_{3}(\mathrm{Pt}) / \mathrm{YSZ} / \mathrm{Pt}, \mathrm{NO}_{2} \text { in air }
$$


The tested sensors were wholly exposed to the same atmosphere, without having the reference electrode separated and exposed to air, contrary to $\mathrm{WO}_{3}$-based electrochemical sensors reported in the literature. ${ }^{13)}$ This fact highly simplifies the sensor design. Moreover, the variations of oxygen concentration can be the same at both electrodes, and their influence might be compensated between the electrodes.

Sensing experiments were performed in a conventional flow apparatus equipped with heating facilities under atmospheric pressure and controlled temperature. The sensors were alternatively exposed to air and various $\mathrm{NO}_{2}$ concentrations (in the range $20-100 \mathrm{ppm}$ ) in air. The gas flow rate was kept constant at $100 \mathrm{~cm}^{3} / \mathrm{min}$. The electrical measurements were performed at controlled temperatures in the $550-700^{\circ} \mathrm{C}$ range. A digital electrometer was used to measure the electromotive force $(\mathrm{EMF})$ between the two electrodes of the YSZ-based sensors. For EMF measurements the $\mathrm{Pt} / \mathrm{WO}_{3}$ sensing electrode was connected to the positive pole of the electrometer. Amperometric measurements were performed applying a constant dc voltage of $\pm 1 \mathrm{~V}$ and measuring the current flowing between the electrodes. Electrochemical impedance spectroscopy (EIS) measurements were carried out in the frequency range from $1 \mathrm{~Hz}$ to 10 $\mathrm{MHz}$ using a Frequency Response Analyzer (FRA, Solartron 1255) coupled with a dielectric interface (Solartron 1296).

\section{Results and discussion}

Figure 1 shows the sensing response of the $\mathrm{WO}_{3}(\mathrm{Pt})$ $\mathrm{YSZ} / \mathrm{Pt}$ sensors at temperatures in the $550-700^{\circ} \mathrm{C}$ range. EMF quickly increased with respect to the Pt electrode (negative as the reference) upon switching from air to 100 ppm $\mathrm{NO}_{2}$. Steady-state values were observed for operating temperatures higher than $600^{\circ} \mathrm{C}$. The higher the operating temperature, the better the stability of the response, and the faster the response time. The response of the $\mathrm{WO}_{3}(\mathrm{Pt})$ $\mathrm{YSZ} / \mathrm{Pt}$ sensor decreased with increasing the temperature, being $39 \mathrm{mV}$ at $550^{\circ} \mathrm{C}$, and $6 \mathrm{mV}$ at $700^{\circ} \mathrm{C}$. The response time (at $90 \%$ of the steady-state value) was 2 min at $550^{\circ} \mathrm{C}$ and less than $20 \mathrm{~s}$ at $700^{\circ} \mathrm{C}(20 \mathrm{~s}$ being the interval of acquisition of the measurements). The $90 \%$ recovery time was $17 \mathrm{~min}$ at $550^{\circ} \mathrm{C}$ and about $2 \mathrm{~min}$ at $700^{\circ} \mathrm{C}$. The good response at $700^{\circ} \mathrm{C}$ is promising for use of this sensor in the control of car exhaust gas.

Figure 2 shows the polarization curves of the $\mathrm{WO}_{3}(\mathrm{Pt})$

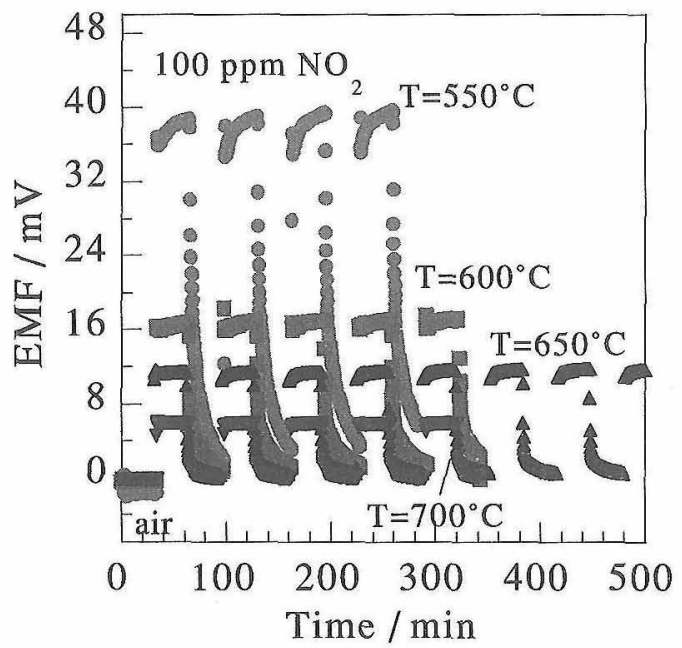

Fig. 1. EMF response of the $\mathrm{WO}_{3}(\mathrm{Pt}) / \mathrm{YSZ} / \mathrm{Pt}$ sensor in cycling air and $100 \mathrm{ppm} \mathrm{NO}_{2}$ in air, measured at selected temperatures.
$\mathrm{YSZ} / \mathrm{Pt}$ cells measured in the voltage range from -2 to $3 \mathrm{~V}$ in air and $100 \mathrm{ppm} \mathrm{NO}$ in air, at $600^{\circ} \mathrm{C}$. For the $\mathrm{Pt} / \mathrm{YSZ} / \mathrm{Pt}$ cell in synthetic air, the current increased (decreased) exponentially for direct (reverse) polarization with a nonlinear, symmetric behaviour. ${ }^{15}$ ) Upon exposure to $\mathrm{NO}_{2}$, the polarization curves shifted upward for direct bias and downward for reverse bias. ${ }^{15}$ ) The polarization curves for the $\mathrm{WO}_{3}(\mathrm{Pt}) / \mathrm{YSZ} / \mathrm{Pt}$ sensor became asymmetric (Fig. 2). A decrease in current was observed for the curves in forward bias (thus, with anodic polarization of the $\mathrm{WO}_{3}$ electrode) upon $\mathrm{NO}_{2}$ exposure, while the curves in reverse bias were almost not affected by $\mathrm{NO}_{2}$ introduction. This suggests that the $\mathrm{WO}_{3}$ electrode plays an important role in promoting the electrochemical reaction of $\mathrm{NO}_{2}$ at the sensing electrode. The same current values observed in air and $\mathrm{NO}_{2}$ upon application of reverse bias seems to indicate $\mathrm{NO}_{2}$ decomposition under cathodic polarization.

Figures 3 and 4 show the results of the amperometric measurements at $600^{\circ} \mathrm{C}$ when a constant dc voltage of $1 \mathrm{~V}$ (Fig. 3) and $-1 \mathrm{~V}$ (Fig. 4) was applied to the $\mathrm{WO}_{3}$ ele-

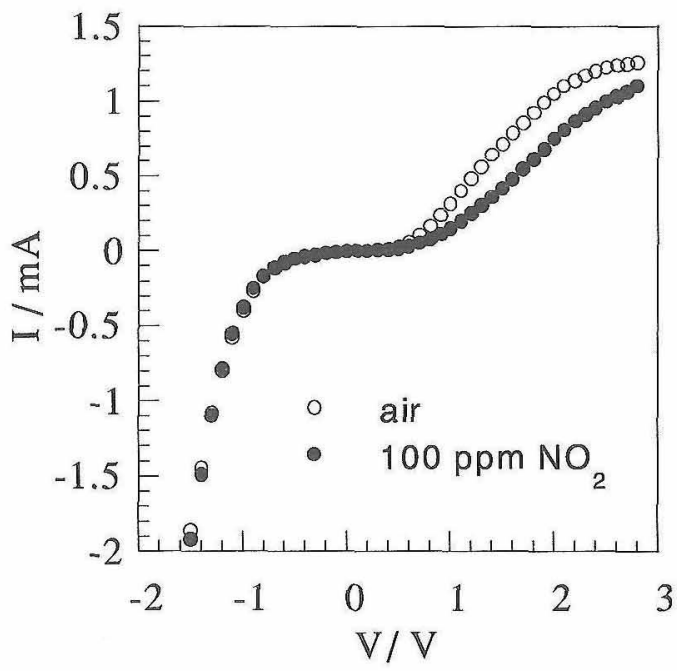

Fig. 2. Polarization curves of the $\mathrm{WO}_{3}(\mathrm{Pt}) / \mathrm{YSZ} / \mathrm{Pt}$ sensor in air and $100 \mathrm{ppm} \mathrm{NO} \mathrm{N}_{2}$ in air, measured at $600^{\circ} \mathrm{C}$.

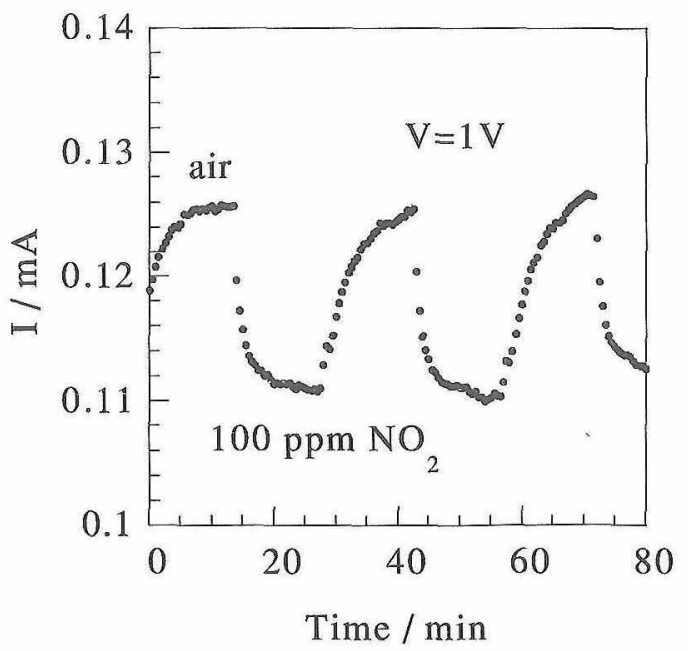

Fig. 3. Amperometric measurements of the $\mathrm{WO}_{3}(\mathrm{Pt}) / \mathrm{YSZ} / \mathrm{Pt}$ sensor in cycling air and $100 \mathrm{ppm} \mathrm{NO}_{2}$ in air, measured at $1 \mathrm{~V}$ and $600^{\circ} \mathrm{C}$. 


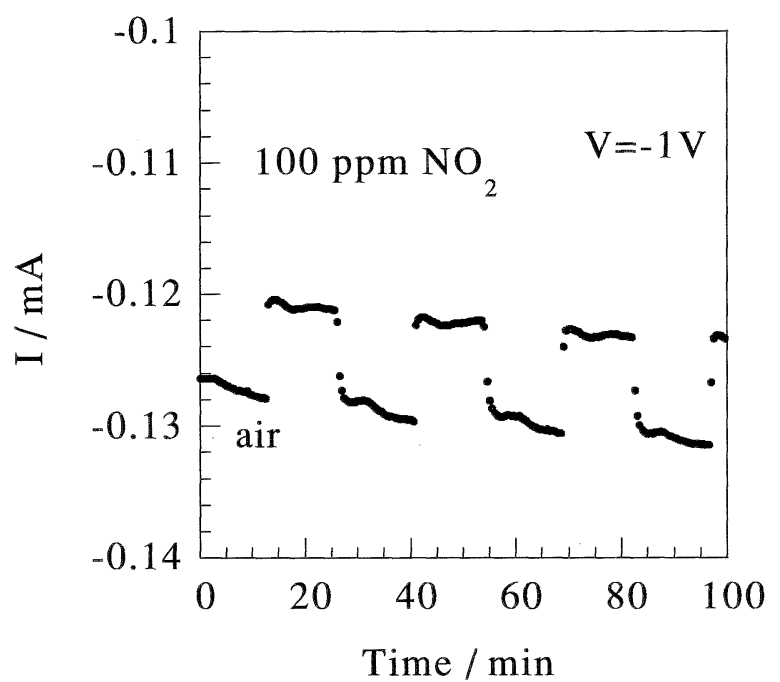

Fig. 4. Amperometric measurements of the $\mathrm{WO}_{3}(\mathrm{Pt}) / \mathrm{YSZ} / \mathrm{Pt}$ sensor in cycling air and $100 \mathrm{ppm} \mathrm{NO}_{2}$ in air, measured at $-1 \mathrm{~V}$ and $600^{\circ} \mathrm{C}$.

ctrode cycling synthetic air and $100 \mathrm{ppm} \mathrm{NO}_{2}$ in air. When applying $1 \mathrm{~V}$, a decrease in the current was observed upon exposure to $\mathrm{NO}_{2}$ gas in agreement with the results of polarization curve measurements. However, the response was rather slow: the response time (calculated at $90 \%$ of the stable value) was about $3 \mathrm{~min}$. The response time was smaller (about $30 \mathrm{~s}$ ) in reverse polarization, but the response was not stable (Fig. 4).

EIS measurements showed both in air and in $100 \mathrm{ppm}$ $\mathrm{NO}_{2}$ in air an arc at high frequencies and a spike at low frequencies, which can be assigned to the impedance of YSZ bulk and to the electrolyte / electrode interface, respectively. ${ }^{15)} \mathrm{NO}_{2}$ exposure did not affect the impedance of YSZ bulk, while the electrolyte/electrode interface was significantly affected. A slight increase in both the resistance $Z^{\prime}$ and reactance $Z^{\prime \prime}$ (Figs. 5(a) and (b)) in the low-frequency region (at the electrolyte/electrode interface) was observed upon introduction of $\mathrm{NO}_{2}$ probably due to an increase in the electrode over-voltage. ${ }^{18)}$ This increase is probably due to the increase in the resistivity of $\mathrm{WO}_{3}, \mathrm{n}$ type semiconductor, upon exposure to $\mathrm{NO}_{2}$, an oxidizing gas. In fact, in similar sensors where the oxide electrode was $\mathrm{LaFeO}_{3}$, a p-type semiconductor, a decrease in both $Z^{\prime}$ and $Z^{\prime \prime}$ was observed upon exposure to $\mathrm{NO}_{2} \cdot{ }^{15}$

Figure 6 shows the linear correlation observed between the EMF response at $600^{\circ} \mathrm{C}$ and the logarithm of $\mathrm{NO}_{2}$ concentration. The slope of the graph was $10.8 \mathrm{mV} /$ decade. Although the correlation is linear, this slope value is inconsistent with a Nernstian equilibrium-type sensor behaviour.

According to the literature, ${ }^{4)}$ the sensing mechanism proposed for electrochemical $\mathrm{NO}_{x}$ sensors based on the combination of YSZ with different metal oxides is based on "mixed potential" theory. A non-Nernstian potential is generated by the following two redox reactions (1) and (2):

$$
\begin{aligned}
& \mathrm{NO}_{2}+2 \mathrm{e}^{-}=\mathrm{NO}+\mathrm{O}^{2-} \\
& \mathrm{O}^{2-}=1 / 2 \mathrm{O}_{2}+2 \mathrm{e}^{-}
\end{aligned}
$$

This mechanism is based on Tafel-type behaviour for YSZ/ metal oxide $\mathrm{NO}_{x}$ sensors using a reference atmosphere. ${ }^{11}$ ) The mixed potential mechanism was also claimed for $\mathrm{CO} /$ $\mathrm{HC}$ gas sensors based on similar electrochemical cells. ${ }^{16), 17), 22)}$

However, for practical applications in automotive field,
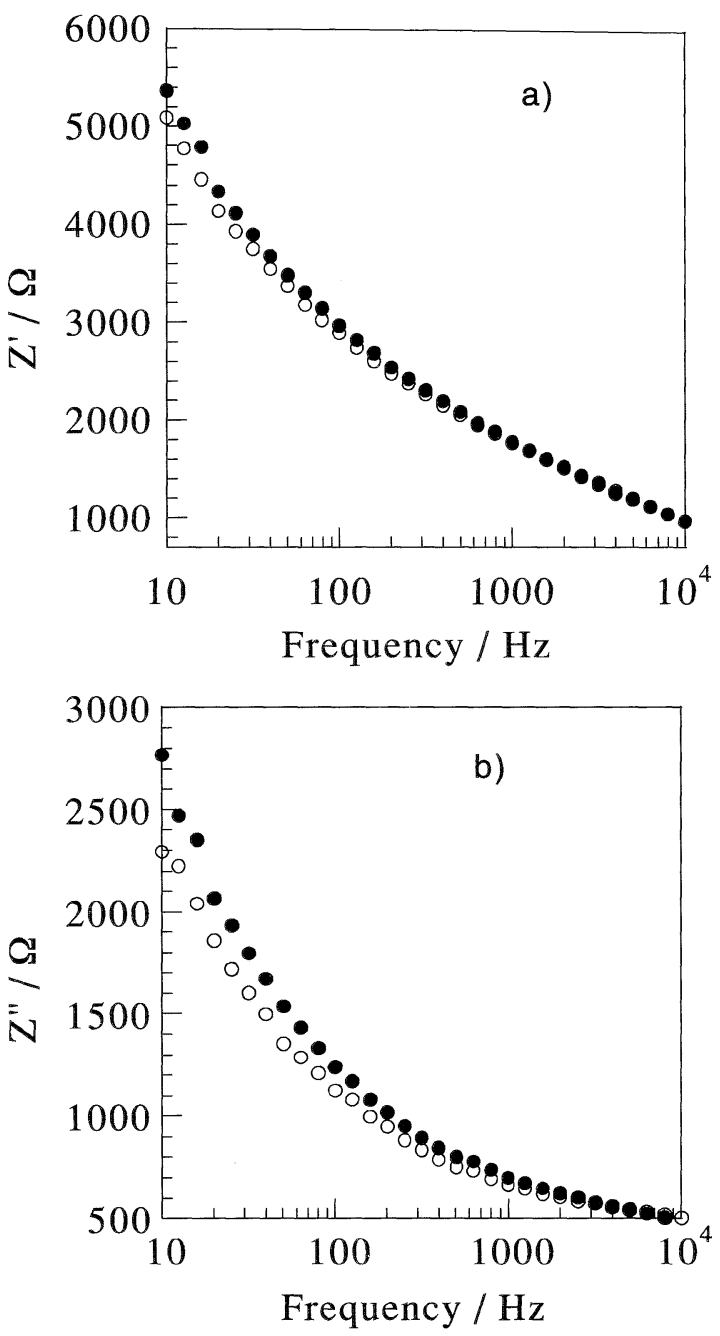

Fig. 5. Resistance $Z^{\prime}$ (a) and reactance $Z^{\prime \prime}$ (b) vs frequency of the $\mathrm{WO}_{3}(\mathrm{Pt}) / \mathrm{YSZ} / \mathrm{Pt}$ sensor at $600^{\circ} \mathrm{C}$ in air (open dots) and in 100 ppm of $\mathrm{NO}_{2}$ in air (full dots).

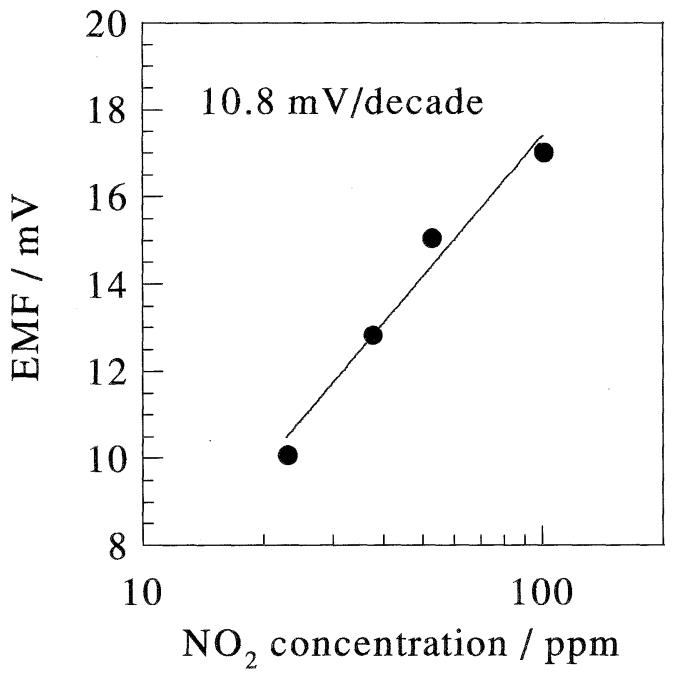

Fig. 6. EMF vs $\log \left(\mathrm{NO}_{2}\right.$ concentration) for the $\mathrm{WO}_{3}(\mathrm{Pt}) / \mathrm{YSZ} /$ Pt sensor at $600^{\circ} \mathrm{C}$.

numerous gaseous species can be present simultaneously in the exhaust stream, generating a non-Nernstian behaviour. 
Therefore, a more general sensing mechanism has been recently proposed that can be more properly described by "differential electrode equilibria." ${ }^{23)}$ The generation of different equilibria between two electrodes exposed to the same gas atmosphere was also proposed recently for the development of single-chamber solid oxide fuel cells. ${ }^{24)}$ It must be pointed out that the definition of the equilibria for applying mixed potential theory to $\mathrm{NO}_{x}$ sensors is difficult because of the complex series of reactions occurring between $\mathrm{NO}$ and $\mathrm{NO}_{2}$ with air, especially at high temperatures. In our case, we should keep in mind that the sensors are not exposed to reference air, and thus the reactions (1) and (2) are assumed to take place at both the sensing and reference electrodes, making the situation more complicated.25) Different electrode equilibria is a more general concept to explain the $\mathrm{NO}_{x}$ sensing mechanism that includes not only the electrochemical reactions, but also the different electrocatalytic activity and/or sorption-desorption behaviour at the two electrodes.

It is possible to explain also our results in terms of different electrode equilibria. ${ }^{25)}$ The number of oxygen ions accumulated at the $\mathrm{WO}_{3}(\mathrm{Pt}) / \mathrm{YSZ}$ and $\mathrm{YSZ} / \mathrm{Pt}$ interfaces upon application of a potential is different, being the former anodic and the latter cathodic regions, and it is also affected by $\mathrm{NO}_{2}$ exposure. Results of EMF measurements and polarization curves clearly indicated that reaction (1) was strongly affected by the electrode materials. Changes in EMF of the $\mathrm{WO}_{3}(\mathrm{Pt}) / \mathrm{YSZ} / \mathrm{Pt}$ upon exposure to $\mathrm{NO}_{2}$ can thus be explained not only by means of electrochemical reactions, but also by a different electrocatalytic activity and/or sorption-desorption behaviour of the two electrodes. ${ }^{22)}$ In fact, $\mathrm{NO}_{2}$ molecules react at the electrolyte/ electrode interface and produce oxygen ions. This reaction is more promoted at the oxide electrode. ${ }^{26)}$ The generated oxygen species are electrochemically pumped through YSZ upon applied potential and give rise to a current through the solid electrolyte. Upon applied potential, the decrease in the current observed upon $\mathrm{NO}_{2}$ exposure can be related to the increase in the resistance and reactance at the electrolyte/ oxide electrode interface due to an increase of the number of oxygen ions accumulated at the $\mathrm{WO}_{3}(\mathrm{Pt}) / \mathrm{YSZ}$ interface. ${ }^{18)}$ This is consistent with the fact that $\mathrm{WO}_{3}$ is an n-type semiconductor: its resistance increases in the presence of oxidising species.

\section{Conclusions}

Electrochemical sensors combining YSZ with $\mathrm{WO}_{3}$ semiconducting oxide as sensing electrode are promising candidates for $\mathrm{NO}_{x}$ detection for emission control of automotive exhaust gas. The use of an oxide as electrode provides thermal and chemical stability of the electrochemical cell, which is extremely important in automotive applications. Moreover, the use of oxides with catalytic properties can improve the selectivity to $\mathrm{NO}_{x}$. Stable EMF values and fast responses have been obtained at a temperature as high as $700^{\circ} \mathrm{C}$. Further studies are needed, however, to better understand the sensing mechanisms of these devices, and to confirm the stability and selectivity in the presence of other exhaust gases, like hydrocarbons, CO, or sulphur compounds.

Acknowledgments This work was partly supported by the National Research Council (CNR) of Italy under the frame of the Targeted Project "Special Materials for Advanced Technologies-MSTA II" and partly by the Ministry of University and
Scientific and Technological Research (MURST) of Italy. One of the authors (A. Dutta) gratefully acknowledges "Programme for Training and Research in Italian Laboratories, ICTP, Trieste" for supporting his stay in Rome.

\section{References}

1) Schwank, J. W. and Di Battista, M., MRS Bull., 24[6], 44-48 (1999).

2) Brosha, E. L., Mukundan, R., Brown, D. R., Garzon, F. H., Visser, J. H., Zanini, M., Zhou, Z. and Logothetis, E. M., Sensors and Actuators B, 69, 171-82 (2000).

3) Oishi, K., "Proc. of the Symposium on Chemical Sensors," Ed. by Butler, M., Ricco, A. and Yamazoe, N., PV 93-97, The Electrochem. Soc. Proc. Series, Pennington, NJ (1993) pp. 443-49.

4) Yamazoe, N. and Miura, N., MRS Bull., 24[6], 37-43 (1999) and references cited therein.

5) Yamazoe, N. and Miura, N., J. Electroceram., 4, 243-55 (1998).

6) Shimizu, Y. and Maeda, K., Chem. Lett., 117-18 (1996).

7) Shimizu, Y. and Maeda, K., Sensors and Actuators B, 52, 84-89 (1998).

8) Di Bartolomeo, E., Traversa, E., Baroncini, M., Kotzeva, V. and Kumar, R. V., J. Eur. Ceram. Soc., 20, 2691-99 (2000).

9) Bredikhin, S., Liu, J. and Weppner, W., Appl. Phys. A, 57, 37-43 (1993)

10) Shimizu, Y. and Yamashita, N., Sensors and Actuators B, 64, 102-06 (2000).

11) Miura, N., Kurosawa, H., Hasei, M., Lu, G. and Yamazoe, N., Solid State Ionics, 86-88, 1069-73 (1996).

12) Lu, G., Miura, N. and Yamazoe, N., J. Mater. Chem., 7, 1445-49 (1997)

13) Lu, G., Miura, N. and Yamazoe, N., Sensors and Actuators B, 65, 125-27 (2000)

14) Miura, N. and Yamazoe, N., "Sensors Update," Vol. 6, Ed. by Baltes, H., Göpel, W. and Hesse, J., Wiley-Vch, Weinheim, Germany (2000) pp. 191-210.

15) Yoon, J. W., Grilli, M. L., Di Bartolomeo, E., Polini, R. and Traversa, E., Sensors and Actuators B, 76, 483-88 (2001).

16) Brosha, E. L., Mukundan, R., Brown, D. R., Garzon, F. H., Visser, J. H., Thompson, D. J., Schonberg, D. H. and Logothetis, E. M., "Solid State Ionic Devices II-Ceramic Sensors," Ed. by Wachsman, E. D., Weppner, W., Traversa, E., Liu, M., Vanysek, P. and Yamazoe, N., The Electrochem. Soc. Proc. Series, Pennington, NJ (2001) pp. 314-21.

17) Hibino, T., Hashimoto, A., Kakimoto, S. and Sano, M., J. Electrochem. Soc., 148, H1-5 (2001).

18) Ho, K. Y., Miyayama, M. and Yanagida, H., J. Ceram. Soc. Japan, 104, 995-99 (1996).

19) Miura, N., Lu, G., Ono, M. and Yamazoe, N., Solid State Ionics, 117, 283-90 (1999).

20) Akiyama, M., Zhang, Z., Tamaki, J., Miura, N., Yamazoe, N. and Harada, T., Sensors and Actuators B, 13-14, 619-20 (1993).

21) Inoue, T., Ohtsuka, K., Yoshida, Y., Matsuura, Y. and Kajiyama, Y., Sensors and Actuators B, 24-25, 388-91 (1995).

22) Miura, M., Raisen, T., Lu, G. and Yamazoe, N., Sensors and Actuators B, 47, 84-91 (1998):

23) Wachsman E. D. and Jayaweera, P., "Solid State Ionic Devices II - Ceramic Sensors," Ed. by Wachsman, E. D., Weppner, W., Traversa, E., Liu, M., Vanysek, P. and Yamazoe, N., The Electrochem. Soc. Proc. Series, Pennington, NJ V1. 32 (2000) pp. 298-304.

24) Hibino, T., Hashimoto, A., Inoue, T., Tokuno, J., Yoshida, S. and Sano, M., Science, 288, 2031-33 (2000).

25) Grilli, M. L., Di Bartolomeo, E. and Traversa, E., J. Electrochem. Soc., 148, H98-102 (2001).

26) Inoue, T., Seki, N., Eguchi K. and Arai, H., J. Electrochem. Soc., 137, 2523-27 (1990) 